Received: November 2, 2017

\title{
Analysis of the Effect of Educational Input on the Entrepreneurial Behavior of Intellectual Employees*
}

\author{
Tao Feng ${ }^{1}$ \\ $X i$ 'an University of Architecture and \\ Technology \\ Chengjun Wang ${ }^{2}$ \\ $X i$ 'an University of Architecture and \\ Technology \\ Xiaoming Sun $^{3}$ \\ Huimin $\mathrm{Li}^{4}$ \\ $X i$ 'an University of Architecture and \\ Technology \\ $X i$ 'an University of Architecture and \\ Technology
}

\begin{abstract}
In the face of the new situation of global economic development and the increasingly severe employment situation, encouraging intellectual employees to start their own businesses and innovate has become a new engine of sustainable economic growth in various countries. Intellectual or technological entrepreneurial activities have never been more active, and their promotion of sustainable economic development has been highly valued by governments all over the world. Educational input in intellectual or technological entrepreneurial employees has played an irreplaceable role in cultivating entrepreneurship and promoting the success rate of starting a business. The educational input of entrepreneurship is an important part and historical mission of continuous education. In order to find the effect of educational input in intellectual employees on entrepreneurial behavior, this study explores the entrepreneurial education system and educational input in the investigated area based on the three-factor interaction theory and the self-efficacy theory, and assesses the positive effect of educational input on the effectiveness of entrepreneurial activities in the area. The results show that continuous input in entrepreneurial education for intellectual employees can not only promote the growth of small-scale entrepreneurial enterprises, but also promote the birth of innovative transnational enterprises.
\end{abstract}

\section{Keywords}

Entrepreneurial educational input $\bullet$ Entrepreneurial behavior $\bullet$ Intellectual employees $\bullet$ Positive effect $\bullet$ Economic growth

\footnotetext{
*1.National Natural Science Foundation of China (71872141): The Impact of The Dynamic Changes of the Newly Key Inventor Collaborative Network characteristics on the Core Technology Breakthrough of Target Enterprises; 2.Soft Science Research Project of Shaanxi Province (2018KRM026): Research on Adaptation, Matching Measurement and Policy Performance of Imported Science and Technology Talents in Shaanxi Province; 3.Social Science Fund Project of Shaanxi Province(2018S45): Research on the Influence Mechanism of the Adaptability of Imported Talents in Shaanxi Province; 4.Talent Fund of Science and Technology of Xi'an University of Architecture and Technology (RC1724)

${ }^{1}$ School of Management, Xi'an University of Architecture and Technology, Xi'an 710055, China. Email: xauatft@ 126.com ${ }^{2}$ Correspondence to: Chengjun Wang (PhD), School of Management, Xi'an University of Architecture and Technology, Xi'an 710055, China. Email: cjwang@ xauat.edu.cn

${ }^{3}$ School of Management, Xi'an University of Architecture and Technology, Xi'an 710055, China. Email:

sun413@xauat.edu.cn

${ }^{4}$ School of Civil Engineering, Xi' an University of Architecture and Technology, Xi' an 710055 China. Email:

li_huimin2005@126.com

Citation: Wang, C. J., Feng, T., Sun, X. M., Li, H. M., Analysis of the Effect of Educational Input on the Entrepreneurial Behavior of Intellectual Employees. Educational Sciences: Theory \& Practice, 18(5), 2430-2437. http://dx.doi.org/10.12738/estp.2018.5.142
} 
In recent years, entrepreneurial research has attracted extensive attention. In fact, the establishment of new companies has become the main driving force of market efficiency, innovation and economic growth in many countries (Acs, Audretsch \& Lehmann, 2013). Scholars have explained how intellectual entrepreneurs transfer knowledge to the market in the form of new enterprises (Arrhenius \& Minniti, 2015). New enterprises have introduced innovative products or created new job opportunities (Gambartella \& Giarratana, 2011), intensified market competition and increased productivity in many industries (Ghio, Niccolò, Guerini, Lehmann \& RossiLamastra, 2015). In spite of these advantages, not everyone is willing to engage in entrepreneurial activity (Autretsch, Lehmann \& Paleari, 2015). It is obvious that entrepreneurs must have enough talents, skills, motivation and other personal traits to engage in entrepreneurship (Plummer \& Acs, 2014). In general, entrepreneurs must invest and adventure in an uncertain and complex risk environment (Knoben, Ponds \& Van Oort, 2011).

There is still debate on whether education can shape entrepreneurship spirit and improve the success rate of entrepreneurship. Whether the outstanding qualities of entrepreneurs are inherent characteristics of individuals or can be trained by nurture education is still controversial (Bonaccorsi, Colombo, Guerini \& Rossi-Lamastra, 2011). In recent years, studies have shown that entrepreneurial abilities can be educated, encouraged, and cultivated as acquired ability (Cattaneo, Meoli \& Signori, 2016). Education can play a key role in shaping and improving the entrepreneurial abilities of entrepreneurs, thereby reducing the uncertainty of entrepreneurship (Zhang, Yang \& Zhou, 2017). Therefore, in recent years, researches on the nature and effect of educational input in intellectual employees' entrepreneurship have been widely carried out. This study is to reveal the positive effect of entrepreneurial educational input in intellectual employees on entrepreneurial activities so as to reduce the risk of newly-created enterprises, and improve the success rate of entrepreneurship and the competitiveness of newly-created enterprises.

This study first analyzes and deals with the core theme of entrepreneurial education for intellectual employees, and discusses key problems that entrepreneurial education should solve in depth by using the threefactor interaction theory and self-efficacy theory from three aspects: recipient, methods and contents of entrepreneurial education, and the person in charge of organization. Then, in-depth statistics and surveys of educational, economic and entrepreneurial activities in a certain area are conducted. Statistical data are obtained and analyzed from the aspects of lifelong education for on-duty and off-duty work, as well as formal and informal education after graduation. Besides, it evaluates the effect of entrepreneurial education input on entrepreneurial activities of intellectual employees. The results show that entrepreneurs are more likely to develop core business if they receive longer entrepreneurial education training and more educational input, and there is also a greater possibility of implementing innovation and invention.

\section{Analysis of Entrepreneurial Education for Intellectual Employees}

Based on the three-factor interaction theory and self-efficacy theory, it is necessary to make an in-depth study and analysis from the following three aspects: recipient of entrepreneurial educational input, methods and 
contents of entrepreneurial education teaching, and the most appropriate organizer of entrepreneurial education so as to analyze entrepreneurial educational input in intellectual employees.

\section{Recipient of entrepreneurial educational input}

What we need to solve first is the question of who is the recipient of entrepreneurial educational input. Entrepreneurship is a complex process with multiple participants. Once a business opportunity is discovered, it is necessary to take action to ensure its safety. The key to distinguish entrepreneurial activities is the need for entrepreneurs to create a new way to realize business opportunities, which are often a new business. The entrepreneurial activity process involves a wide variety of participants. Generally speaking, the image of an entrepreneur is related to a person who is innovative, flexible, dynamic, willing to take risks, creative, and growing. In most cases, the independent and innovative entrepreneur is responsible for bringing fundamental change and innovation to the market. Other participants are also involved in the creation of innovations and new businesses, such as those responsible for equally important marginal innovations in the development of new projects, sponsors (including business angel investors or risk investors) and decision makers. All of these participants can be the object of entrepreneurial education because a better understanding of their respective capabilities can promote a higher level of entrepreneurial activity.

\section{Methods and contents of entrepreneurial education}

The contents and methods of teaching and training in entrepreneurial education, the suitability of entrepreneurial teaching, what to teach and how to teach are very important issues. The effect of entrepreneurial education depends on its active or reflective teaching mode, and also on the specific forms and contents of teaching curriculum. The design of the educational process plays an important role in the different but very relevant abilities of individuals engaged in the activities of innovation and entrepreneurship. On the one hand, education provides technical capacity and a grasp of available analytical tools for future entrepreneurs and others who participate in activities related to innovation and growth. On the other hand, education can stimulate creativity and imagination and promote their rational and full use of resources. What calls for special attention is that there is a fundamental difference between entrepreneurial education and business management education. Although learning to manage an enterprise is a common factor, learning some of the additional key skills is also involved in starting a business. These additional skills include innovation, risk-taking, and the flexibility to use scarce resources in an uncertain environment. In addition, these additional skills are mainly obtained through learning from a variety of experience, such as writing a business plan, entrepreneurship of intellectual employees, consultations and interviews with entrepreneurs, computer simulation, role play, simulation, standpoint analysis, management of relevant personnel of the enterprise; research and study of a successful entrepreneurial company. These additional skills are critical to entrepreneurial education for intellectual employees, so the curriculum for entrepreneurial education should include subjects that may involve and require knowledge and skills to be obtained from, for example, engineering, science, economics, and humanities. 


\section{Organizer of entrepreneurial education}

It is also an important problem that who is the most appropriate and scientific to organize and be responsible for entrepreneurial educational input. Although general researchers majoring in entrepreneurial education are also able to teach entrepreneurship in the general sense at all levels of entrepreneurial education, they don't know how to establish an effective link between practical and risky entrepreneurial activities and professional and in-depth academic activities. How to put students in a real entrepreneurial environment is a problem that every organizer and person in charge of entrepreneurial education must face. In other words, if teachers themselves haven't experienced risk education, how can they teach risk education? The teacher-centered teaching method only requires students to learn abstract theoretical concepts and obtain general concept knowledge. Therefore, entrepreneurial education requires the existence of entrepreneurial experts as errorcorrecting persons for entrepreneurial theory and teacher dominance. The integration of entrepreneurs and entrepreneurship into entrepreneurial teaching can adopt many forms that depend on the teaching intent of entrepreneurial education. A major challenge is how to make entrepreneurs participate in entrepreneurial education instead of just teaching students what to do. What entrepreneurs do is something other people don't want to do or can't do. Two marked features of entrepreneurship are continuous innovation and creativity. The unique and innovative ways of thinking and active ability of entrepreneurs are crucial. The organizer and the person in charge of entrepreneurial education must have the same innovation ability as the entrepreneur, and must involve the students in the process of cultivating the unique ability of the entrepreneur.

\section{Assessment on the Effect of Entrepreneurial Education Input on Entrepreneurial Activities of Intellectual Employees}

In-depth statistics and survey are carried out on educational, economic and entrepreneurial activities in a certain area. Statistical data are obtained from the aspects of lifelong education for on-duty and off-duty work, as well as formal and informal education after graduation to assess the effect of entrepreneurial educational in

\section{Entrepreneurial activities, local education and economy in the investigated area}

The investigated Sindu consists of Suemei partition, Suecao partition and Shituo partition. Sindu covers an area of about 8,000 square kilometers with a population of about 200,000. From 2014 to 2017, the total entrepreneurial activity rate in Sindu was between $5 \%$ and $7 \%$. This means that about $5 \%$ to $7 \%$ of adults participated in the entrepreneurial process during this period. The sample size for the Sindu was from 2,000 sample surveys, about $15 \%$ of which came from Suemei partition, $55 \%$ from the Suecao partition, and $30 \%$ from the Shituo partition. This weight ratio accurately reflects the true distribution of residents in these three partitions.

According to the endogenous growth theory in economics, the ability of any economy entity to develop and increase wealth is directly related to the endowment of its human resource level which can be provided by the educational level. The higher the educational level is, the greater the ability of the economic entity for growth 
$\overline{\text { and development is. On average, people participating in entrepreneurial activities earn a higher education degree }}$ on average than the rest of the population, indicating that education is positively related to risk-taking and willingness to start a business, and people with higher education degree are more likely to engage in entrepreneurial activities.

\section{Lifelong, on-duty and off-duty entrepreneurial education}

In order to have stronger economic competitiveness, the investigated area must have good human resources and a stable entrepreneurial ecosystem so that every employee can create a new enterprise, take risks, generate new knowledge and innovate capabilities. This requires the design of a scientific entrepreneurial educational program to enable intellectual employees to acquire skills and capabilities they should have in both on-duty and off-duty situations.

We distinguish two aspects of entrepreneurial education. One is on-duty education, including professional knowledge and entrepreneurial education during work, and the other is off-duty education, mainly referring to entrepreneurial education after work. More specifically, this study investigates the proportion of people who receive relevant training during the work, and the proportion of employees who continue to receive entrepreneurship training after leaving work, as shown in the following table.

Table 1

Population of Involved in Entrepreneurship Training

\begin{tabular}{lcc}
\hline & on-the-job/\% & off-the-job/\% \\
\hline Sindu & 11.3 & 13.2 \\
Suewei & 10.3 & 12.0 \\
Suecao & 10.4 & 12.9 \\
Shituo & 12.4 & 14.7 \\
\hline
\end{tabular}

The results in the above table show that most employees accept the way of education and training after leaving work. We believe that the input in entrepreneurial education should be carried out in various forms systematically and continuously at different time periods so that employees can continue to improve their entrepreneurial skills and abilities in a flexible and autonomous manner.

\section{Standardized entrepreneurial education, formal and informal entrepreneurial p education after graduation}

At present, most people choose to choose to accept entrepreneurial education after becoming employees after graduation. After graduation, entrepreneurial education must be distinguished between formal entrepreneurial education and informal entrepreneurial education. Formal entrepreneurial education refers to the entrepreneurial education input for obtaining a degree in a specific education plan while entrepreneurial education input mainly includes typical entrepreneurship training institutions such as chambers of commerce, government agencies, and enterprise incubation centers, as shown in the following table.

In recent years, the training programs for intellectual entrepreneurial education have become more and more popular in the investigated area. As shown in the above table, nearly $65 \%$ of intellectual employees in the 
$\overline{\text { investigated area take part in formal university education and training after graduation. Universities and higher }}$ education institutions are more concerned with providing entrepreneurial education and training to employees. Although students in business-related fields are more receptive to such education than students in other subjects, the latter trainees are not opposed to participate to accommodate more intellectual employee students from different majors. Although Suemei has the highest proportion of people trained in formal entrepreneurial education in the investigated area, the flow of talents is a common phenomenon locally and globally.

Table 2

Formal and Informal Entrepreneurial Education

\begin{tabular}{lcccccc}
\hline & Formal & \multicolumn{3}{c}{ Informal } \\
\cline { 2 - 7 } & $\begin{array}{c}\text { University/ } \\
\text { College }\end{array}$ & $\begin{array}{c}\text { University/ } \\
\text { College }\end{array}$ & Business asoc. & Public agencies & Self studies & Others \\
\hline Sindu & 64.9 & 57.9 & 42.1 & 37.6 & 61.9 & 54.8 \\
Suewei & 84.3 & 59.8 & 43.9 & 42.5 & 67.9 & 55.2 \\
Suecao & 64.5 & 58.9 & 51.4 & 42.4 & 57.4 & 54.9 \\
Shituo & 67.3 & 57.2 & 38.8 & 40.9 & 73.5 & 57.0 \\
\hline
\end{tabular}

The degree of participation in informal entrepreneurial education is also quite significant. On the one hand, entrepreneurship is fostered; on the other hand, for the creation of truly innovative enterprises, startup projects have become a real venture created by the staff and faculty in the investigated area.

In summary, entrepreneurial education and training program with different approaches have been developed and strengthened over time in the investigated area. Understanding successful cases in other parts of the world and taking advantage of regional educational input programs can provide more comprehensive suggestions for entrepreneurial education training.

\section{Effect of entrepreneurial educational input}

The ultimate goal of most entrepreneurial education is the success rate of employees in starting up a business. One way to measure the effect of entrepreneurial education is to calculate the percentage of entrepreneurs that these programs generate, and to determine the type of enterprises that intellectual employees create. How much money they raise in start-ups and whether the enterprises they create are internationalized and innovative-driven are also important measurement indexes. It is also noted that the proportion of employees who have a longer training period in entrepreneurial education is higher, and the proportion of entrepreneurs who start new companies is also higher, as shown in the table below.

Table 3

Entrepreneurship and longevity of training

\begin{tabular}{lcc}
\hline & With training either in-the-job or off-the-job & With training both in-the-job and off-the-job \\
\hline Sindu & 7.9 & 8.4 \\
Suewei & 13.2 & 7.3 \\
Suecao & 6.4 & 6.8 \\
Shituo & 8.6 & 12.5 \\
\hline
\end{tabular}

Finally, the characteristics of the companies created by entrepreneurs who have received intensive entrepreneurial educational input are analyzed, including the industrial sector of start-ups, the 
internationalization and innovation-driven nature, and the number of start-up funds. Our results show that after a long training period in entrepreneurial education, it is more likely to develop core business and implement innovative inventions, as shown in the table 4.

Table 4

Effectiveness of Entrepreneurial Education

\begin{tabular}{lcccc}
\hline & college & internationalization & \multicolumn{2}{c}{ innovation } \\
\cline { 2 - 5 } & $\begin{array}{c}\text { Entrepreneur } \\
\text { with college\% }\end{array}$ & $\begin{array}{c}\text { \%with customers in } \\
\text { other countries }\end{array}$ & $\begin{array}{c}\text { \%with new } \\
\text { technology }\end{array}$ & $\begin{array}{c}\text { \% with new } \\
\text { product } \\
\text { market }\end{array}$ \\
\hline $\begin{array}{l}\text { Entrepreneur without } \\
\text { training in lifetime }\end{array}$ & 29.5 & 31.2 & 10.2 & 19.8 \\
$\begin{array}{l}\text { Entrepreneur with } \\
\text { training form and } \\
\text { inform }\end{array}$ & 49.8 & 52.3 & 35.9 & 92.6 \\
\hline
\end{tabular}

\section{Conclusion}

This study first puts forward the argument whether the educational input can shape the entrepreneurship spirit and improve the success rate of entrepreneurship, and then discusses the key problems that entrepreneurial education should solve in depth by using the three-factor interaction theory and self-efficacy theory from three aspects, namely, recipient, methods and contents of entrepreneurial education, and the person in charge of organization. Then, an in-depth study is carried out on the educational, economic and entrepreneurial activities in a certain area to evaluate the effect of entrepreneurial input on the entrepreneurial activities of intellectual employees from life-long education of both on-duty and off-duty situations, as well as the formal and informal education after graduation. The results show that when intellectual employees receive more educational input, the new enterprises are more likely to carry out core business, and the possibility of implementing innovative inventions is also greater.

\section{References}

Acs, Z., Audretsch, D. B., \& Lehmann, E. E. (2013). The knowledge spillover theory of entrepreneurship. Small Business Economics, 41(4), 757-774. http://dx.doi.org/10.1093/acprof:oso/9780195183511.003.0003

Arenius, P., \& Minniti, M. (2015). Perceptual variables and nascent entrepreneurship. Small Business Economics, 24(3), 233-247. http://dx.doi.org/10.1007/s11187-005-1984-x

Gambardella, A., \& Giarratana, M. (2011). Localized knowledge spillovers and skill - biased performance. Strategic Entrepreneurship Journal, 4(4), 323-339. http://dx.doi.org/10.1002/sej.99

Ghio, Niccolò, Guerini, M., Lehmann, E. E., \& Rossi-Lamastra, C. (2015). The emergence of the knowledge spillover theory of entrepreneurship. Small Business Economics, 44(1), 1-18. http://dx.doi.org/10.1007/s11187-014-9588-y 
Audretsch, D. B., Lehmann, E. E., \& Paleari, S. (2015). Academic policy and entrepreneurship: A European perspective. Journal of Technology Transfer, 40(3), 363-368. http://dx.doi.org/10.1007/s10961-014-93596.

Plummer, L. A., \& Acs, Z. J. (2014). Localized competition in the knowledge spillover theory of

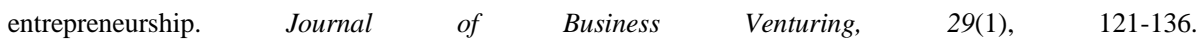
http://dx.doi.org/10.1016/j.jbusvent.2012.10.003

Knoben, J., Ponds, R., \& Van Oort, F. (2011). Employment from new firm formation in the Netherlands: Agglomeration economies and the knowledge spillover theory of entrepreneurship. Entrepreneurship \& Regional Development, 23(3-4), 135-157. http://dx.doi.org/10.1080/08985620903183736

Bonaccorsi, A., Colombo, M. G., Guerini, M., \& Rossi-Lamastra, C. (2013). University specialization and new firm creation across industries. Small Business Economics, 41(4), 837-863. http://dx.doi.org/10.1007/s11187-013-9509-5

Cattaneo, M., Meoli, M., \& Signori, A. (2016). Performance-based funding and university research productivity: The moderating effect of university legitimacy. The Journal of Technology Transfer, 41(1), 85-104. http://dx.doi.org/10.1007/s10961-014-9379-2

Zhang, P., Yang, Z., \& Zhou, X. (2017). Centralization and innovation performance in an emerging economy: testing the moderating effects. Asia Pacific Journal of Management, 32(2), 415-442. http://dx.doi.org/10.1007/s10490-014-9394-8 